\title{
IMPLEMENTATION OF INCLUSIVE PEDAGOGY IN THE TEACHING OF CHEMISTRY
}

\section{[IMPLEMENTACE INKLUZIVNI PEDAGOGIKY DO VYUKY CHEMIE]}

\section{Jitka Lorenzova}

doi: 10.18355/PG.2021.10.2.2

\begin{abstract}
The aim of the article is to draw attention to the context that inclusive understanding of pedagogy brings to the education of natural sciences with an emphasis on the teaching of chemistry and to open a debate for cooperation in the fields of social and special pedagogy and the methodology of teaching chemistry. In the article, inclusion is understood as a process of creating and improving the learning conditions of all students, taking into account the broader dimensions of heterogeneity, diversity, and language, as well as cognitive and physical barriers that may occur during the teaching of chemistry. The main focus is centered on the concept of science literacy for all, out of which comes the requirement to link inclusive pedagogical principles and the goals of natural sciences education. We bring to attention the need to increase the sensitivity of chemistry teachers to differences that may have a negative impact on learning outcomes, as well as the need for targeted teacher training for leading inclusive classes and for assessing their level of competence required for inclusive teaching.
\end{abstract}

\section{Key words}

Inclusive education, heterogeneity, and diversity, chemistry teaching, science literacy for all, didactics of chemistry

\section{Anotace}

Cílem článku je upozornit na souvislosti, které přináší inkluzivní chápání pedagogiky do prŕrodovědného vzdělávání s důrazem na výuku chemie a otevř́ít debatu nezbytnou pro spolupráci sociální a speciální pedagogiky a didaktiky chemie. Inkluze je $\mathrm{v}$ článku chápána jako proces vytváření a zlepšování podmínek pro učení všech žáků se zohledněním širších dimenzí heterogenity a diverzity a jazykových, kognitivních a fyzických bariér, které mohou ve výuce chemie nastat. Pozornost je zaměřena na koncept př́rodovědné gramotnosti pro všechny, z něhož vychází požadavek na propojení inkluzivních pedagogických principů a cílů př́rodovědného vzdělávání. Je upozorněno na potřebu zvyšování senzitivity učitelů chemie vůči rozdílům, které mohou mít negativní dopad na výsledky učení, stejně jako na potřebu cílené př́pravy učitelů pro inkluzivní vedení školní třídy a pro posouzení úrovně jejich vlastní kompetence k inkluzivní výuce. 


\section{Klíčová slova}

Inkluzivní vzdělávání, heterogenita a diverzita, výuka chemie, přírodovědná gramotnost pro všechny, didaktika chemie

\section{1. Úvod}

Inkluze ve smyslu společného vzdělávání žáků má svoje kořeny v prohlášení UNESCO z roku 1994 a aktuálně je jedním z obecných cílů evropského školství do roku 2030 (UNESCO, 2015). V diskursu soudobých vzdělávacích politik je zaštítěna právem rovného prŕstupu ke kvalitnímu vzdělávání a vytváření příležitostí k učení pro všechny. Také v ČR je inkluze jedním z nejdůležitějších témat transformace školství, proto ani oblast př́rodovědného vzdělávání nemůže zůstat stranou. Dosud však chybí i v mezinárodní perspektivě koncepční rámec, který by inkluzivní pedagogiku uvedl do souvislosti s didaktikou přírodních věd (Stinken-Rösner, Rott, Hundertmark. et. al., 2020). Podobně je tomu v př́padě didaktiky chemie.

Chemie je jedním z klíčových př́rodovědných oborů a jako taková je integrální součástí všeobecného vzdělání. Někteří odborníci (Abels, 2015) ale upozorňují, že její tradiční chápání jako „tvrdé“ vědy, založené na porozumění abstraktním pojmům, teoriím a modelům, nemusí být s inkluzivním pojetím výuky kompatibilní. V zahraničí však existují studie, které se na vztah inkluzivní pedagogiky a chemie zaměřují (Abels, 2015; Menthe, Hoffmann, 2015; Abels, Kolliander, Plots, 2020; Tolsdorf, Kousa, Markic, Aksela, 2018; Abels, 2019; Heidinger, Abels, Plotz, Koliandr, 2017; Mumba, Banda, Chabalengula, Dolenc, 2015). Cílem článku proto je upozornit na souvislosti, které přináší inkluzivní pedagogika do př́rodovědného vzdělávání, $\mathrm{s}$ důrazem na výuku chemie, a otevřít i v podmínkách středoevropského regionu debatu směrem k promýšlení problematiky a $\mathrm{k}$ větší interdisciplinární spolupráci na poli sociální a speciální pedagogiky a oborové didaktiky.

\section{Pojetí inkluzivního vzdělávání - vymezení rámce}

Inkluze ve vzdělávání je aktuálně často skloňovaným pojmem, jeho vymezení však není jednotné. V užším smyslu znamená, že žáci se speciálními vzdělávacími potřebami mají právo učit se společně s ostatními v podmínkách, které jejich potřebám odpovídají, a že vzdělávací systém má povinnost jim tyto podmínky vytvořit (Adamus, Zuzulkova, Kaleja \& Franiok, 2016). Inkluze je následně pojata jako právo na vzdělávání těchto žáků v hlavním proudu s využitím specifických nástrojů, pro která se vžilo označení podpůrná opatření - v ČR stanovena novelou školského zákona s platností od 1. záŕí 2016 (Zákon 82/2015 Sb.). K těmto opatření patří např. úprava metod, forem, obsahu a organizace vzdělávání žáka, úprava očekávaných výsledků učení a jejich hodnocení, systémové začlenění asistentů pedagoga do výuky nebo specifická podpora žáka, jako např. využití tlumočníka do znakového jazyka nebo průvodce pro orientaci v prostoru. Vedle toho však zůstala zachována také možnost zřizovat speciální oddělení, skupinu, třídu nebo školu pro žáky se závažnějšími speciálními vzdělávacími potřebami (mentální, tělesné, zrakové nebo sluchové postižení, závažnější vývojové poruchy učení a chování, dětský 
autismus apod.), což je z hlediska ideje společného vzdělávání krajní, přesto využívané opatření.

V širším pojetí (Booth, Ainscow, 2007) je inkluze procesem vytváření a zlepšování podmínek pro učení všech žáků se zohledněním šířeji chápaných dimenzí heterogenity a diverzity, ve kterých se žáci navzájem odlišují (pohlaví, věk, kultura, etnická příslušnost, náboženství, jazyk, socioekonomické pozadí, gender a sexuální identita, životní podmínky a biografické zkušenosti atd.). V tomto pojetí se inkluze zaměřuje méně na specifické postupy a více na využití zdrojů, které jsou běžně $\mathrm{k}$ dispozici $\mathrm{v}$ praxi škol a které lze zapojit do zvládání rozdílnosti žáků (Florian, 2010).

Přestože jsou si pojmy heterogenita a diverzita v pedagogickém diskursu blízké, i mezi nimi ještě existuje významové odstínění. V paradigmatu heterogenity je rozdílnost ve vzdělávání chápána spíše jako náročná výzva, s níž je třeba se aktivně vypořádat; paradigma diverzity ji naopak pojímá spíše jako výhodu a důležitý zdroj pro učení (Sliwka, 2010). Toto druhé pojetí např. více odpovídá chápání diverzity v globálních firmách, ve kterých je oceňováno zapojení jednotlivců s různými přístupy do řešení problémů (Miner, Nieman, Swanson, Woods, 2001). V obou př́ípadech ale jde o vytvoření vzdělávacího prostředí s rozmanitými př́ležitostmi $\mathrm{k}$ učení, na kterých se mohou všichni žáci a žákyně v rámci třídy a školy podílet (Florian, 2010; Florian, Linklater, 2010).

\section{Principy inkluzivní pedagogiky ve výuce chemie}

Základní filozofií inkluzivního přístupu ve vzdělávání je, že každý žák a student má potenciál, který lze využít jako zdroj pro učení. Úkolem učitele je tento potenciál rozpoznat a respektovat bez diskriminačních účinků, aby nedocházelo k marginalizaci žáků a jejich vyloučení z procesů učení (Booth, Ainscow, 2007; Florian, Spratt, 2013; Mastropieri, Scruggs, 2014). V důsledku této filozofie se tedy učitelé mají méně soustředit na tradiční otázku, kdo je nebo není schopen se učit, a více na to, co se má naučit a jakým zpo̊sobem (Florian, Black-Hawkins, 2011). Přijetí tohoto postoje předpokládá, že učitel chemie bude uvažovat o své výuce v intencích principů inkluzivní pedagogiky. V základním vymezení k nim patří (StinkenRösner, Rott, Hundertmark. et. al., 2020): uznání rozmanitosti, rozpoznání překážek a umožnění účasti.

Uznání rozmanitosti vyžaduje, aby učitel přistupoval k žákům jako $\mathrm{k}$ nehomogenní skupině a měl na zřeteli, že ji tvoří jedinečné osobnosti s individuální biografií a životní zkušeností, zájmy a potřebami, rozdílným sociálním, kulturním a jazykovým zázemím. Důležitá je vnímavost učitele vưči všemu, co může blokovat vzdělávací př́íležitosti (Stinken-Rösner, Rott, Hundertmark et. al., 2020). Přestože v minulosti se od těchto aspektů víceméně odhlíželo, dnes panuje shoda, že právě rozdílnost zcela zásadně určuje podmínky a cesty učení (Florian, Spratt, 2013). Např. je prokázáno, že v chemii se horší výsledky častěji objevují nejen u žáků s problémy v učení, ale také u těch, kteří pocházejí z rodin s nižším socio-ekonomickým statusem nebo u žáků s migrační zkušeností (Kousa, Kavonius, Aksela, 2018).

V rámci principu rozpoznání překážek je vhodní mít na zřeteli, že ve výuce chemie se lze setkat se specifickými bariérami fyzickými, 
př́strojovými i prostorovými. Laboratoře a učebny mnohdy nejsou uzpůsobeny žákům se zdravotním postižením, přístroje se nacházejí mimo jejich dosah a ovládací prvky často nejsou upraveny tak, aby je tito žáci mohli používat - stávají se pak pasivními účastníky dění, aniž by se mohli aktivně podílet na provedení experimentu (Stinken-Rösner, Rott, Hundertmark et. al., 2020). Tím je narušen klíčový inkluzivní princip účasti. Také experimentování v heterogenních učebních skupinách je velmi náročné organizačně. Je třeba nejen vytvořit podpůrné podmínky pro učení, ale také zajistit bezpečnost žáků. To vyžaduje opatření, která mohou v důsledku mnoho učitelů odrazovat od konání experimentů a přiklánět je spíše $\mathrm{k}$ naukovému pojetí výuky, což je v př́ípadě chemie $\mathrm{v}$ př́íkrém rozporu s duchem této vědy.

Další bariéry mohou být spojeny s jazykem vědy. Speciálně jazyk chemie je vzhledem ke své formálnosti pro mnohé žáky náročný anebo neznámý (Markic, Childs, 2016) a často je hlavní překážkou pro učení se obsahu, a to bez ohledu na skutečné schopnosti žáků (Stinken-Rösner, Rott, Hundertmark et. al., 2020).

Pokud učitelé chemie chtějí, aby se u žáků vytvořily vědecké formy myšlení a jazyka, je důležité rozvíjet je postupně, vhodnými psychologickými a komunikačními prostředky. Wellington a Osborne (2009) se domnívají, že i s žáky, u kterých se objevují rozdíly v oblasti jejich jazykové výbavy, lze diskutovat velmi vědecky, pokud učitel užívá správný druh srozumitelného jazyka na podporu deduktivního i induktivní uvažování, formulování hypotéz, zobecnění, spojování tezí s důkazy apod. Tím opět může pomoci žákům participovat, překonat obavy ze selhání a nechut' $\mathrm{k}$ výuce chemie jako takové.

Výzkumy ukazují, že nejlépe je inkluzivní učení chemie podporováno v prostředí, kde existují jasné postupy, pravidla a důsledky, jakož i jasnost a struktura obsahu (Pawlak, Groß, 2020). Nicméně, pokud jde o obsah, právě v chemii existuje riziko vzniku specifických kognitivních bariér. Napr̆. pochopit, že svět přírody včetně lidské fyzické existence se odvíjí od složitého komplexu skrytých chemických reakcí a dějů, je pro mnoho žáků vysoce náročný úkol. Je doloženo, že čím je obsah vzdělání abstraktnější, tím vyšší je možnost, že bude překážkou učení (Stinken-Rösner, Rott, Hundertmark et. al., 2020). Žák (Fernandez-Lopez, Moreno-Sanchez, 2008) musí primárně změnit způsob, jakým jsou organizovány jeho subjektivní teorie, a pochopit, že realitu lze interpretovat $\mathrm{z}$ pohledu modelů a formálních vzorců (epistemologická změna) a že skutečnost, ke které svoje teorie vztahuje, je v procesu neustálé proměny (změna ontologická). Jako kognitivní překážky mohou působit také miskoncepty, které si žáci přinášejí do výuky z vlastní každodenní zkušenosti.

V psychologickém smyslu je zásadní překážkou také malá motivace k učení. Vzhledem k tomu, že každý jednotlivec má různé zájmy, měla by je inkluzivní výuka chemie u žáků zohlednit (Stinken-Rösner, Rott, Hundertmark. et. al., 2020). Po učitele je důležité vědět, že rozdíly v zájmech žáků jsou při školní vědecké činnosti zvláště významné a mají vliv na kvalitu zvládnutí obsahu (Höft, Bernholt, Blankenburg, Winberg, 2019). Např́íklad (tamtéž) v sekundárním vzdělávání již není tak důležitý realistický zájem, 
který je spojený s prováděním experimentů vedených instrukcí, přičemž ale tato forma obvykle převažuje. Mnozí žáci naopak dávají přednost zájmům výzkumným (plánování experimentů $\mathrm{k}$ prozkoumání něčeho), uměleckým (nakreslení pozorování), podnikavým (organizování malého chemického projektu) nebo networkingovým (rozhovory se spolužáky o chemických tématech) Každý z uvedených zájmů by proto měl být učitelem ve výuce chemie oceňován a podporován.

Princip účasti znamená aktivní zapojení skutečně všech žáků do výuky chemie. Je důležité podtrhnout (Booth, Ainscow, 2007), že pojem „zapojení“ má v inkluzivní pedagogice hluboký sociální a emoční význam od učitele vyžaduje organizovat výuku tak, aby všichni žáci zažívali proces učení ve spolupráci, mohli se do učení aktivně a bez obav ze selhání ponořit a aby měli vliv na to, jak jejich učení probíhá. Podmínkou zapojení je vnitřní vnímané uznání a sebepřijetí, které se z podstatné části vytváří ve vzájemných sociálních interakcích. Učitelé, jako subjektivně významné osoby, by měli žákům vytvořit při učení pocit bezpečí, považovat jejich individuální nápady, zájmy nebo schopnosti za podnětné a umožnit jim spolurozhodovat o obsahu učení (Stinken-Rösner, Rott, Hundertmark et. al., 2020). Z moderních teorií vnitřní motivace (např. teorie sebedeterminace Ryana a Deciho) plyne, že vyšší angažovanost, soustředěnost a vytrvalost se udrží jen vnímáním sebeurčeného chování. $V$ rámci inkluzivní výuky chemie je tedy důležité, aby všichni žáci vnímali svoji činnost jako autonomní, vnitřně obohacující, produktivní a hodnotnou (Höft, Bernholt, Blankenburg, Winberg, 2019).

\subsection{Vztah inkluzivních principů a cílů př́rodovědné gramotnosti}

Př́rodovědná gramotnost je chápána jako schopnost jedince poznat a pochopit roli, kterou hrají př́rodní vědy ve světě, racionálně usuzovat, zdůvodňovat a proniknout do př́rodních věd tak, aby splňovaly jeho životní potřeby jako tvořivého, občansky aktivního a přemýšlivého občana (Černocký, Hedvábná, Herink, et. al., 2011). Ve společnosti založené na moderních technologiích je přírodovědné vzdělávání a získání přírodovědné gramotnosti klíčovým předpokladem úspěšného sociálního začlenění (Walkowiak, Rott, Abels, Nehring, 2018). Výuka př́rodovědných předmětů tedy přispívá $\mathrm{k}$ širšímu chápání inkluze naplňováním cílů přírodovědné gramotnosti, ke kterým patří (Hodson, 2014): schopnost žáků uvažovat o vědeckých otázkách, konceptuální porozumění obsahu, „dělání vědy“ a pronikání do podstaty vědy. Tyto cíle mají být dosaženy u všech žáků a studentů, proto lze ideu inkluzivní pedagogiky v prírodovědném vzdělávání vyjádřit také heslem „přírodovědná gramotnost pro všechny“ (StinkenRösner, Rott, Hundertmark et. al., 2020) ${ }^{3}$.

Prvním krokem $\mathrm{k}$ dosažení přírodovědné gramotnosti je nabídka relevantních vědeckých problémů a otázek, které vycházejí z každodenních zkušeností žáků (Stinken-Rösner, Rott, Hundertmark et. al., 2020)³. Chemie samotná nabízí mnoho otázek, které jsou spojeny s jejich každodenním životem, např́ílad vliv kyselého deště na životní prostředí, zkušenost s korozí kovových předmětů, problém biologicky odbouratelného odpadu, záhada složení oblíbené potraviny, každodenní užívání oděvů s vysokým 
podílem syntetických vláken... Sám vědecký problém nebo otázka ale ještě nejsou vlastním obsahem výuky, důležité jsou jako stimulující a motivační kontext, který podporuje zájem žáků o pochopení tajů prírodního světa (Stinken-Rösner, Rott, Hundertmark et. al., 2020).

Druhý cíl se týká koncepčního porozumění, tradičně řečeno, vlastního vzdělávacího obsahu. $\mathrm{V}$ př́rodních vědách a ve výuce chemie je pro žáky zřejmě nejobtížnější propojení viditelných a hmatatelných objektů a jevů s jejich vysvětleními, které často vyžaduje znalosti o skrytých procesech, jež nelze prŕmo pozorovat (Hodson, 2014). Např́iklad, pokud žáci nepochopí počáteční koncepty týkající se prvků periodické tabulky, budou mít problémy i v dalším učení založeném na její aplikaci (Mastropieri, Scruggs, 2014). $\mathrm{V}$ takovém a podobných př́ípadech platí, že pokud nemohou ve výuce chemie rozvíjet svoje porozumění, mají slabší výsledky i horší vztah $\mathrm{k}$ předmětu jako takovému (Kousa, Kovonius, Aksela).

„Dělání vědy“ je třetím cílem prrírodovědného vzdělávání. Důraz by měl být kladen na používání vědeckých metod a postupů $\mathrm{k}$ vyšetřování jevů, řešení problémů a rozvíjení zájmů. Vzhledem $\mathrm{k}$ různorodým zájmům, schopnostem a různým znalostem žáků je třeba nabídnout různé činnosti, jako je demonstrace, rrízená praxe a aplikace (Hodson, 2014). Výzkumy totiž ukazují, že individuální zájem o vědu není ani tak prričinou, jako spíše důsledkem zajímavého způsobu získávání znalostí (Höft, Bernholt, Blankenburg, Winberg, 2019).

Čtvrtý cíl se týká poznávání podstaty vědy. Žáci mají pochopit, že smyslem vědy je objektivní pravdivé poznání založené na pozorování a experimentech, poznat různé oblasti spolupráce s dalšími obory a postupně pronikat do problematiky vztahu vědy a společnosti (Hodson, 2014), a to včetně rizik, které věda a technika mohou přinášet. Také tento mezioborový kontext otevírá další oblasti pro rozmanité príležitosti k učení (StinkenRösner, Rott, Hundertmark. et. al., 2020).

Je evidentní, že cílů prírodovědné gramotnosti pro všechny lze ve výuce dosáhnout pouze tehdy, pokud učitelé vezmou v úvahu jak vědeckou, tak inkluzivní perspektivu. V tomto smyslu by si měli klást na všech třech úrovních principů inkluzivní pedagogiky a ve vztahu ke čtyřem kategoriím cílů např́ílad následující otázky (Stinken-Rösner, Rott, Hundertmark. et. al., 2020): Na úrovni uznání diverzity: Jaké vědecké otázky, kontexty, obsahy a experimenty budou stimulující pro všechny žáky? Jaké dimenze diverzity hrají roli při uvažování o těchto otázkách, kontextech, obsazích a experimentech? Jaké individuální znalosti, dovednosti a zkušenosti žáků mohou být využity jako zdroje? Na úrovni identifikace bariér: S jakými překážkami nebo výzvami se mohou žáci $\mathrm{v}$ rámci různých dimenzí cílů setkat? Jak mohou být stávající zdroje užity pro překonání bariér nebo výzev spojených s problémem? Na úrovni zapojení: Jakým způsobem může být určitý kontext, obsah, procedura nebo vědecká otázka skutečně zpř́stupněna zkušenosti všech žáků? Důsledný trénink v uvažování o těchto otázkách by se zároveň měl stát součástí př́pravy budoucích učitelů. 


\subsection{Učitel chemie v inkluzivní tř́́dě}

Ve vzdělávání není nic neutrální, jakákoli věc, kterou učitel udělá, má na vliv, at' pozitivní nebo negativní (Hart, Dixon, Drummond, McIntyre, 2004, s. 261). To platí i pro inkluzi. Učitel chemie se může např́íklad pokusit heterogenitu a diverzitu ve trrídě ignorovat, může se snažit jí přizpůsobit nebo podporovat studenty individuálně pomocí specificky diferencovaných úkolů (Tolsdorf, Markic, 2017). Velmi často je ale bezradný. Obvykle nemá dostatečnou průpravu pro inkluzivní výuku, a proto nedokáže propojit cíle př́rodovědné gramotnosti s inkluzivními principy. Také nemá povědomí o tom, jaké druhy rozdílů a překážek při učení existují a jak se na nich může podílet samotné studijní prostř̌edí; $\mathrm{z}$ dosavadních poznatků také plyne, že budoucí učitelé jen zřídka znají více než jednu dimenzi heterogenity a rozmanitosti, které se mohou ve výuce chemie projevit (Tolsdorf, Kousa, Markic, Aksela, 2018). Proto by jim měla být poskytována intenzivnější př́íprava v oblasti účinných strategií pro inkluzivní výuku (Mumba, Banda, Chabalengula, Dolenc, 2015). Také efektivní mentoring pro začínající učitele a trénink dovedností ohledně managementu inkluzivní třídy (Pawlak, Groß, 2020) by jistě pomohly lepšímu zvládnutí heterogenity.

Učitelé by zároveň měli mít představu o svých kompetencích $\mathrm{k}$ inkluzivní výuce a umět využít $\mathrm{k}$ jejich zhodnocení $\mathrm{k}$ tomu vytvořené měřicí škály (Sharma. Loreman, Forlin, 2012). Podobně je důležité umět diagnostikovat inkluzivní prostředí třídy a školy, například s využitím některého z nástrojů zjištujících index inkluze (Menthe, Hoffmann, 2015), a účinně řešit diskriminační účinky rozdílů, které mají vliv na výsledky učení Tolsdorf, Markic, 2017). Zároveň by se měli vyvarovat některých dobře míněných ,inkluzivních omylů“. Například pouhé užívání participativního diskursu ve výuce chemie ze strany učitele na podporu pocitu začlenění a přijetí u žáků nestačí $\mathrm{k}$ tomu, aby bylo dosaženo koncepčních cílů výuky (Abels, Koliander, Plots, 2020). Nestačí ani provádění experimentů vedených instrukcí. Výzkumy naznačují, že řízené praktické aktivity, které jsou typické pro výuku přírodních věd v sekundárním vzdělávání, ukazují pouze malou pozitivní korelaci s koncepčním porozuměním, na rozdíl od aktivit výzkumných, sociálních, podnikavých nebo sítových (Höft, Bernholt, Blankenburg, Winberg, 2019). Pozitivní vliv na podporu učení všech žáků má naopak peer-tutoring, které má větší efekt z hlediska učebních výsledků než učení individuální nebo kolaborativní. Zároveň vede, na rozdíl od doučování staršími studenty, ke zvýšení akademické angažovanosti a převzetí kontroly nad vlastním učením, a to zejména u žáků s oslabeným výkonem (Adamus, Zuzulkova, Kaleja, Franiok, 2016), kteří jsou nejvíce ohroženi neúspěchem.

\section{Závěr}

Inkluze ve vzdělávání je relativně diverzifikovaný a v praxi nesmírně náročný pedagogický koncept, přičemž její aplikace do výuky chemie není dosud dostatečně prozkoumaná. Na jedné straně se zaměřuje na jednotlivce a skupiny dětí, u nichž bylo zjištěno, že jsou obzvláště zranitelné, pokud jde o dosahování vzdělávacích výsledků, na druhé straně je inkluze obecnější 
přístup, který klade důraz na společné učení a na to, co je součástí vzdělávacích zkušeností všech žáků (Florian, Marty, Black-Hawkins, 2011). Úkolem učitele chemie je vytvářet podmínky pro učení, které pomáhají všem žákům zapojit se do vzdělávacího procesu a posilují jejich kompetenci $\mathrm{k}$ učení. Vodítkem je důsledné propojení inkluzivních pedagogických principů $\mathrm{s}$ cíli př́rodovědné gramotnosti. To je jistě náročné, ale $\mathrm{z}$ pohledu kvalitního vzdělávání pro všechny v oblasti přírodních věd jedině možné.

Přestože je inkluze prosazována decizní sférou i odborníky a mnohými učiteli je verbálně přijímána, výzkumy učitelské profese dokládají, že existuje rozdíl mezi tím, co učitelé ríkají o tom, jak vyučují, a tím, jak skutečně jednají ve tř́dě. Toto jednání se řídí jejich implicitními koncepcemi, které mají často přednost před explicitním diskurzem a je obtížnější je měnit (Scheuer, Perez, Mateos, Pozo, 2006). Do budoucna je v tomto smyslu důležité zkoumat, zda a do jaké míry se učitelé chemie ztotožňují s inkluzivní pedagogikou, stejně jako jejich implicitní přesvědčení o smyslu takové výuky. Zcela zásadní je zvýšení vnímavosti učitelů vucči rozdílům, které se mohou promítat do procesu učení (dodejme, že nejen negativně, ale i pozitivně, např́iklad u žáků nadaných). Taková změna není v rámci tradiční orientace na žáky se speciálními potřebami jednoduchá. Modely př́pravy a dalšího vzdělávání učitelů by proto měly zohlednit více dimenzí heterogenity a diverzity, $\mathrm{s}$ nimiž se mohou učitelé chemie v praxi setkat, a zaměřit se na zlepšení jejich kompetencí $\mathrm{v}$ oblasti inkluzivního vedení výuky a managementu tř́dy.

\section{Bibliographic references}

ABELS, S. 2015. Scaffolding inquiry-based science and chemistry education in inclusive classrooms. In YATES, N. L. (Ed.). New developments in science education research. New York City: Nova Science Publishers, pp. 7796. ISBN 978-1-63463-914-9.

ABELS, S. 2019. Science Teacher Professional Development for Inclusive Practice. International Journal of Physics \& Chemistry Education, vol. 11, n. 1, pp. 19-29. ISSN 2589-8876.

ABELS, S. - KOLIANDER, B. - PLOTS, T. 2020. Conflicting Demands of Chemistry and Inclusive Teaching - A Video-Based Case Study. Education Sciences, vol. 10, n. 30, 50 [accessed Mar 30, 2021]. ISSN 2227-7102. Available online: https://doi.org/10.3390/educsci10030050

ADAMUS, P. - ZEZULKOVA, E. - KALEJA, M. - FRANIOK, P. 2016. Inkluzivni vzdelavani $\mathrm{V}$ kontextu promen ceskeho skolstvi. Ostrava: Ostravska univerzita, Pedagogicka fakulta. ISBN 978-80-7464-884-7.

BOOTH, T. - AINSCOW, W. 2007. Ukazatel inkluze. Rozvoj uceni a zapojeni ve skolach. Praha: Rhythmus. ISBN 80-903598-5-X.

CERNOCKY, B. - HEDVABNA, B. - HERINK, J. ET. AL. 2011. Prirodovedna gramotnost ve vyuce. NUV: Praha: NUV, ISBN 978-80-8700074-8.

EDUCATION 2030. 2015. Incheon Declaration and Framework for Action Towards inclusive and equitable quality education and lifelong learning for all. Paris: UNESCO. Available online: https://unesdoc.unesco.org/ark:/48223/pf0000245656 
FERNANDEZ-LOPEZ, J. A. - MORENO-SANCHEZ, J. I. 2008. La Quimica en el aula: entre la ciencia y la magia. In Jornadas sobre nuevas tendencias en la ensenanza de las ciencias y las ingenierias, Murcia, Oct 1618, 2008. Murcia: Consejo Escolar de la Región de Murcia.

FLORIAN, L. 2010. The concept of inclusive pedagogy. In HALLETT, G., HALLETT, F. (Eds.). Transforming the role of the SENCO, pp. 61-71. Berkshire: Open University Press. ISBN 978-0335242412.

FLORIAN, L. - BLACK-HAWKINS, K. 2011. Exploring inclusive pedagogy. British Educational Research Journal, vol. 37, n. 5, pp. 813-828. ISSN 0141-1926.

FLORIAN, L. - LINKLATER, H. 2010. Preparing teachers for inclusive education: using inclusive pedagogy to enhance teaching and learning for all. Cambridge Journal of Education, vol. 40, n. 4, pp. 369-386. ISSN 0305764X.

FLORIAN, L. - MARTY, R. - BLACK-HAWKINS, K. 2011. Researching achievement and inclusion to improve the educational experiences and outcomes of all learners. Aula: Revista de Pedagogía de la Universidad de Salamanca, n. 17, pp. 57-72. ISSN 0214-3402.

FLORIAN, L. - SPRATT, J. 2013. Enacting inclusion: a framework for interrogating inclusive practice. European Journal of Special Needs Education, n. 28, pp. 119-135. ISSN 0885-6257.

HART, S. - DIXON, A. - DRUMMOND, M. J. - McINTYRE, D. 2004. Learning without limits. Maidenhead: Open University Press. ISBN 9780335212590 .

HEIDINGER, C. - ABELS, S. - PLOTZ, T. - KOLIANDER, B. 2018. Inclusion and Chemistry teaching - Deliberating Conflicting Demands. In FINLAYSON, O. E., McLOUGHLIN, E., ERDURAN, S., CHILDS, P. (Eds.). Electronic Proceedings of the ESERA 2017 Conference. Research, Practice and Collaboration in Science Education, pp. 1611-1619. Dublin: Dublin City University. ISBN 978-1-873769-84-3.

HODSON, D. 2014. Learning Science, Learning about Science, Doing Science: Different goals demand different learning methods. International Journal of Science Education, vol. 36, n. 15, pp. 2534-2553. ISSN 09500693.

HÖFT, L. - BERNHOLT, S. - BLANKENBURG, J. S. - WINBERG, M. 2019. Knowing more about things you care less about: Cross-sectional analysis of the opposing trend and interplay between conceptual understanding and interest in secondary school chemistry. Journal of Research in Science Teaching, vol. 56, n. 2, pp. 184-210. ISSN 0022-4308. KOUSA, P. - KAVONIUS, R. - AKSELA, M. 2018. Low-achieving students' attitudes towards chemistry and it's teaching methods. Chemistry Education Research and Practice, vol. 19, n. 2, pp. 431-441 ISSN 1756-1108. Available online: https://doi.org/10.1039/C7RP00226B

MARKIC, S. - CHILDS, P. E. 2016. Language and the teaching and learning of chemistry. Chemistry Education Research and Practice [online], vol. 17, n. 3, pp. 434-438. ISSN 1756-1108. Available online: https://doi.org/10.1039/C6RP90006B 
MASTROPIERI, M. A. - SCRUGGS, T. E. 2014. The inclusive classroom: Strategies for effective differentiated instruction, 5th ed. Boston: Pearson. ISBN 978-0132659857.

MENTHE, J. - HOFFMANN, T. 2015. Inklusiver Chemieunterricht: Chance und Herausforderung. In RIEGERT, J., MUSENBERG, O. (Eds.). Inklusiver Fachunterricht in der Sekundarstufe, pp. 131-140. Stuttgart: Kohlhammer. ISBN 978-3170252035.

MINER, D. L. - NIEMAN, R. - SWANSON, A. B. - WOODS, M. 2001. Teaching Chemistry to Students with Disabilities: A Manual for High Schools, Colleges, and Graduate Programs. 4th Edition. Washington, DC: American Chemical Society Committee on Chemists with Disabilities. ISBN 0-8412-3817-0.

MUMBA, F. - BANDA, A. - CHABALENGULA, V. M. - DOLENC, N. 2015. Chemistry teachers' perceived benefits and challenges of inquiry-based instruction in inclusive chemistry classrooms. Science Education International, vol 26, n. 2, pp. 180-194. ISSN 2077-2327. Available online: http://www.icaseonline.net/sei/june2015/p5.pdf

PAWLAK, F. - GROß, K. 2020. Using Classroom-Management to Support Inclusive Chemistry Learning. In LEVRINI, O., TASQUIER, G. (Eds.). Electronic Proceedings of the ESERA 2019 Conference. The beauty and pleasure of understanding: engaging with contemporary challenges through science education. Bologna: University of Bologna, pp. 359-366. ISBN 97888-945874-0-1.

SCHEUER, N. - PEREZ, P. - MATEOS, M. - POZO, J. 2006. Las teorias implicitas sobre el aprendizaje y la ensenanza. In SCHEUER, N. ET. AL. Nuevas formas de pensar la enseñanza y el aprendizaje. Barcelona: Grao, pp. 95-134. ISBN 84-7827-432-4.

SHARMA, U. - LOREMAN, T. - FORLIN, C. 2012. Measuring teacher efficacy to implement inclusive practices: An international validation. Journal of Research in Special Educational Needs [online], vol. 12, n. 1, pp. 12-21. ISSN 1471-3802. Available online: https://doi.org/10.1111/j.14713802.2011.01200.x

SLIWKA, A. 2010. From homogeneity to diversity in German education. In OECD (Ed.) Educating teachers for diversity: Meeting the challenge, pp. 205-217. Paris: OECD Publishing. Available online: https://doi.org/10.1787/9789264079731-12-en

STINKEN-RÖSNER, L. - ROTT, L. - HUNDERTMARK, S. BAUMANN, TH. - MENTHE, J. - HOFFMANN, TH. - NEHRING, A. ABELS, S. 2020. Thinking Inclusive Science Education from two Perspectives: Inclusive Pedagogy and Science Education. RISTAL. Research in Subject-matter Teaching and Learning, n. 3, pp. 30-45 ISSN 2616-7697. Available online: https://doi.org/10.23770/rt1831

THE SALAMANCA STATEMENT AND FRAMEWORK FOR ACTION ON SPECIAL NEEDS EDUCATION. Adopted by the World Conference on Special Needs Education: Access and Quality Salamanca, Spain, 7-10 June 1994. Paris: UNESCO. Available online: https://unesdoc.unesco.org/ark:/48223/pf0000098427 
TOLSDORF, Y. - KOUSA, P. - MARKIC, S. - AKSELA, M. 2018. Learning to Teach at Heterogeneous and Diverse Chemistry Classes Methods for University Chemistry Teacher Training Courses. EURASIA Journal of Mathematics, Science and Technology Education [online], vol. 14, n. 10, pp. 1-14. ISSN 1305-8223. Available online: https://doi.org/10.29333/ejmste/93377.

TOLSDORF, Y. - MARKIC, S. 2017. Development of an Instrument and Evaluation Pattern for the Analysis of Chemistry Student Teachers' Diagnostic Competence. International Journal of Physics and Chemistry Education n. 9, pp. 1-10 [accessed Feb 20, 2021]. ISSN 2589-8876. Available online: https://doi.org/10.12973/ijpce/80707.

WALKOWIAK, M. - ROTT, L. - ABELS, S. - NEHRING, A. 2018. Network and Work for Inclusive Science Education. In EILKS, I., MARKIC, S., RALLE, B., (Eds.). Building Bridges Across Disciplines. Aachen: Shaker, pp. 269-274, cit. p. 270. ISBN 978-3844062557.

WELLINGTON, J. J. - OSBORNE, J. 2009. Language and literacy in science education; Buckingham: Open Univ. Press. ISBN 0335205992.

ZAKON 82/2015 SB., kterym se meni zakon č. 561/2004 Sb., o predskolnim, zakladnim, strednim, vyssim odbornem a jinem vzdelavani, skolsky zakon, ve zneni pozdejsich predpisu. Available online: https://www.zakonyprolidi.cz/cs/2015-82

doc. PhDr. Jitka Lorenzova, Ph.D.

Department of Education and Human Sciences

University of Chemistry and Technology, Prague

Technicka 5

Dejvice

16628 Praha 6

Czech Republic

jitka.lorenzova@vscht.cz 